\title{
HIDDEN AFFINITIES OF ANDREY BELY AND OTOKAR BŘEZINA
}

JAN VOREL

ABSTRACT In the article we aim to compare aesthetic worlds of A. Bely and O. Březina. We have concluded that they both created philosophical and aesthetical systems having directed symbolism to be understood as a complex of means of more profound cognition of reality.

KEY WORDS Russian and Czech Symbolism, Andrey Bely, Otokar Březina, Theory of Symbol and Symbolism, Theurgy, the Sense of Art

CONTACT University of Ostrava, Faculty of Arts, Department of Slavonic Studies; jan.vorel@osu.cz 
The aim of the study is to compare the essayistic work of art of two symbolistic poets - Andrey Bely and Otokar Březina. Both authors represent the highest level of the genesis of symbolistic stream in Russian and Czech literature of the beginning of $20^{\text {th }}$ century, called the "theurgy" by a famous Russian philosopher. We will try to compare their aesthetic-philosophical approaches to art and, consequently, to find common elements of their work of art.

\section{$1 /$ AESTHETICS OF A. BELY}

Bely's efforts to understand fundamental problems of the aesthetics and philosophy of symbolism are, above all, reflected in his study "Основы моего мировоззрения" (1922). There he tries to anchor the symbolism with contemporary philosophical systems (Schopenhauer, Nietzsche, Solovyov, neo-Kantianism), but mainly with anthroposophy of R. Steiner. At the beginning of the study, Bely pays attention to the question of the perception and understanding of the world which is tightly connected with the problem of the essence, style and causality: “мировоззрение не есть только что (реализм, идеализм), но и как (гностический, или мистический, или логический идеализм и т. д.); и для чего (для рассудка, для жизненной практики, для себя, для других и т. д.)”. (Белый 1995: 13)

Then Bely tries to formulate postulates that in general represent the base of literary symbolism. The way to the real and undistorted perception of the reality, according to Bely, leads to the abstraction of totality composed of elements permeated each other: “Искомому мировоззрению ставлю императив; оно должно удовлетворять нас 1) гносеологически, 2) эстетически и 3) этически; если оно не удовлетворяет нас в одном только пункте, оно не мировоззрение. Мировоззрение - индивидуальный путь к целому, где целое - храм о многих дверях". (Белый 1995: 14, 21) ${ }^{1}$ Thus symbolistic art is understood as a connection of aesthetics and logics; and the knowledge is transformed into "aesthetical emblematics of philosophical sense” (“мировоззрение в смысле всегда - эстетический феномен”). (Белый 1995: 21)

\section{2 / THE ART}

Bely's thinking about symbolism and modern art is based on the question of the sense and intention of art creating. Bely comes to conclusion that every art is the creative activity of human soul. The phenomenon of cognition and the searching for the sense is the integral part of this activity, which makes our being reasonable. Thus, the art becomes the parallel to the gnoseology: “Теория символизма в таком освещении одинаково изучает законы мифического творчества, как и законы мистического, эстетического и всякого иного творчества, не подчиняя эти законы эстетике, ни обратно: не подчиняя эстетику, например, религии. Она не противостоит ни науке, ни метафизике, ни религии, ни искусству, а только теории познания". (Белый 1994: 126)

According to Bely the art also melts the pictures of life into the pictures filled with axiological dimension. This understanding of art is closer to the religion, because both are able to

1 Dtto, s. 14, 21. Here Bely's inspiration were also the theories of V. S. Solovyov (“Тут я близок в задании к вопросу Владимира Соловьева: как возможно нам иельное знание". [Белый 1995: 14]). In particular, it is Solovyov's book "Философские начала цельного знания" (1877), where the integral knowledge ("free theosophy") is understood as a complex of mystical, psychic and physical phenomenons. 
create new forms of being and transform humankind to the spiritual level: “...в искусстве есть живой огонь религиозного творчества...то, что начинается в искусстве, заканчивается в религии. Искусство, образуя с религией и этикой однородную группу ценностей, все же ближе к религии, чем к этике, поэтому в глубине целей, выдвигаемых искусством, таятся религиозные цели: эти цели - преображение человечества, создание новых форм". (Белый 1994: 125, 115)

Bely also claims that every kind of art is symbolical in its deepest essence, because it represents organic connection of phenomena of outer world and the living consciousness. This connection is in its essence the integrity of outer and inner worlds and its sense could be uncovered through the metaphysics and the mystics that show the way to the comprehensive transformation of our being. In connection with these theories he understands the symbol as the interaction of its three elements: 1) symbol as a picture of visible reality which arouses certain emotions in our consciousness, 2) symbol as an allegory which expresses ideological sense of the picture (philosophical, religious and social sense), 3) symbol as a call for creation of the real life. Interaction of these elements creates symbolistic picture as a living entity in human consciousness: “Трехчленное символическое построение: 1) образ (плоть), 2) идея (слово), 3) живая связь, преопределяющая и идею, и образ (слово, ставшее плотью)". (Белый 1994:124)

Bely, subsequently, thinks about the question which way we can reach real symbolistic art. Like Nietzsche and Wagner he finds the ideal bases and roots of contemporary culture in Ancient Mysteries that represented the state of organic unity of all art forms. Further, genesis of art leads to an endless differentiation and disintegration that causes fragmentation of human psyche and destroys our former organic worldview. For that reason, tendencies to the new synthesis of art forms are symptomatic for symbolistic aesthetics: “...возникает стремление к мистерии как к синтезу всех возможных форм”. (Белый 1994: 142) Bely also underlines the importance of the presence of living religious sense in renewed mysteries. These changes in aesthetic canon could only lead to the transformation of the world of human consciousness and the creation of organic culture: "Мы должны забыть настоящее: мы должны все снова пересоздать: для этого мы должны создать самих себя. И единственная круча, по которой мы можем карабкаться, это мы сами. На вершине нас ждет Я. Вот ответ для художника: если он может остаться художником, не переставая быть человеком, он должен стать своей собственной художественной формой. Только эта форма творчества еще сулит нам спасение. Тут и лежит путь будущего искусства". (Белый 1994: 143-144)

One of the main targets of contemporary art is for Bely its gradual cultivation towards its ability to overcome the state of dead and mechanic forms and take up creative approach to the life, which leads to creating of living forms. And, finally, the art creation must be tightly connected with knowledge. The absence of this connection is the cause of the crisis of contemporary culture: “Как машина человек подчиняется законам необходимости... Дух говорит нам, что в нас творческое начало жизни. Всякое искусство начинается там, где человеческий дух, хотя бы и бессознательно, провозглашает примат творчества над познанием. Свободная воля есть воля творческая. Искусство окрыляется там, где призыв к творчеству есть вместе с тем призыв к жизни". (Белый 1994:154)

In essayistic works and the work of art of A. Bely, we can naturally find influences of philosophy of V. S. Solovyov. A. Bely became a passionate follower of Solovyov (he started to study 
his works in 1900) and he was mainly interested in Solovyov's theory of "theurgy", which is presented as a synergy of aesthetic and religious sphere and as the conviction that the art creation could participate in the transformation of the world. Influenced by Solovyov's theories about religious sense of art, Bely believed (see e.g. “Луг зеленый", 1910) that every aesthetic form could open the way to the Absolute and the art could become the means of metamorphoses of the essential forms of life: “Искусство - кратчайший путь к религии...творчество, проведенное до конца, непосредственно переходит в религиозное творчество - теургию”. [...] “Наш путь, в соединении земли с небом, жизни с религией, долга с творчеством...” (Белый 1910: $230,61)$

In 1903 Bely published in the journal Новый путь (issue 9) an article under the heading «O теургии» that is usually considered to be the manifesto of Russian symbolism. Here Bely was convinced that the epoch when humankind was able to expand the borders of its spiritual life is arriving now. The real art according to Bely is always connected with theurgy. But it is necessary to renew and cultivate "the theurgic element of word" which is understood as "divinely creative essence". The word becomes a prayer where art and mysticism meet.

In essence, Bely's creative experiments represent permanent searching for hidden sense in the chaos of outer forms; searching for hidden connection between "inner word" and its outer aural versions and establishing the balance between spontaneity and spirituality. "Inner word" with its energy according to Bely is turning into outer aural realisation and just in this process the opening of the sense and the genesis of consciousness of the aural version is realising. The word that lives its independent spiritual life inside of every human being and that is always the representation of the Soul becomes the Logos. Logos takes part in realization of every aural version. In this process the "inspirational root of the poetry" is hidden; it is actually the cause of the transformation of the profane human being into the spiritual one. The creating artist now becomes the "holder of inner word", the Poet-Theurgist.

In the mentioned article, Bely in accordance with Solovyov philosophy tries to formulate the idea of spiritual, psychological, physiological and physical transformation of contemporary human, which is the first step to the Solovyov's Divine Humanity. In human unconscious Bely finds (similarly as C. G. Jung) the knot thanks to which every human being is connected to the divinity and thanks to it that is possible to see ourselves as a small space, which is the part of the highest unity. At this moment we can only hear "long forgotten music": “...когда в восторге стоишь среди шумящих деревьев, охваченный чувством вознесенности над историей, потому что время свернулось, и все, что было, что есть и что будет - все слилось в давно позабытую вновь зазвучавшую музыку, и этот закон - дверь из мира к тому, что за миром. Стоишь с разведенными руками и прося не за себя, не за близких, не за родину, а за весь мир...”. (Белый 2005: 120, 122)

Inspired by V. S. Solovyov's synthetism, Bely was increasingly interested in the problems of connection of contemporary art and the evolution of human thought. By the realisation of this connection Bely tried to find new ways of reception, expression and the state of being when artistic pictures could evoke not only the feeling of beauty, but they also could become the means of knowledge. The symbolism is, in fact, the ability of recognition of secret signs in nature "Theurgical sense of art" (the unity of microcosm and macrocosm) as the greatest ambition of art is finally realised here. 


\section{3 / THE WORD}

In his study called "Магия слов" (1910), Bely characterizes the nature of symbolical language of art as a "word magic", which helps artist to express inexpressible perceptions incurred by actuation of reality to his consciousness. Living speech is seen as "music of inexpressible". Creative word makes new world of sound symbols that elucidates all mysteries of outer world and inner world of human being that reflects reality: "В слове дано первородное творчество; слово связывает бессловесный, незримый мир, который роится в подсознательной глубине моего личного сознания с её словесным, бессмысленным миром, который роится вне моей личности. Слово создает новый третий мир - мир звуковых символов... мир внешний проливается в мою душу, мир внутренний проливается из меня в зори, в шум деревьев; в слове, и только в слове воссоздаю я для себя окружающее меня извне и извнутри, ибо я - слово и только слово”. (Белый 1994: 131)

The existence of the world is conditional on the existence of words. The world according to Bely is created with the help of "sound symbols - metaphors" (metaphor is understood as a memory of primal myth). If any word is mainly reflected as the sound, Bely sees the fundamental moment in shaping them through the "victory of sound symbols" that causes the birth of pictures, rhythms and new worlds: “...всякое слово есть звук. Если бы не существовало слов, не существовало бы и мира. Мое я, оторванное от всего окружающего, не существует вообще; мир, оторванный от меня, не существует тоже; я и мир возникают только в процессе соединения их в звуке... Слово - символ; оно есть понятное для меня соединение двух непонятных сущностей: доступному моему зрению пространства и глухозвучащего во мне внутреннего чувства, которое я называю условно (формально) временем...звук соединяет пространство со временем... пространственные отношения он сводит к временным... звук есть объективизация времени и пространства". (Белый 1910: 430)

The intention of art to create pictures based on arising of new word and life relations indicates that words are able to create and conjure the world and to resurrect lost sense: “...слово есть заклятие вещей; слово есть призыв и вызывание Бога... Когда я говорю я, я создаю звуковой символ; я утверждаю этот символ как существующий; только в эту минуту я создаю себя. (Белый 1910: 440) [...] И потому-то новое слово жизни в эпоху всеобщего упадка вынашивается в поэзии. Мы упиваемся словами, потому что сознаем значение новых, магических слов, которыми вновь и вновь сумеем заклясть мрак, нависающий над нами. Мы еще живы - но мы живы потому, что держимся за слова. Наши дети выкуют из светящихся слов новый символ веры; кризис познания покажется им лишь только смертью старых слов. Человечество живо, пока существует поэзия языка; поэзия языка жива. Мы живы”. (Белый 1994: 142)

Bely's thinking about the word is close to his theories of culture as a genesis of consciousness representing the way to primary significance. The evolution of world culture according to him now runs in the name of decentralization and fragmentation of human existence. He sees the evolution as the process of gradual separating of human counciousness from primary unity and he divides this process into three periods. The first period is presented as the "state of Paradise", which represents the unity of counsciousness and cosmic essence. For the next period the creation of pictures is symptomatic. Symbols, myths, religions are born at this period. The 
third period represents the origin of "thoughts of objects" as the concepts that symbolise the solid states of matter (stone and ice) and negative aspect of life that turn to death from one hand and the liquid and gaseous from to the other hand (water and fire) like positive aspects that turn to dissolution in unity.

The way from decentralized being is according to Bely possible only through re-establishing the unity between being, pictures and concepts. At the start of the process of restoring the integrity it is necessary to read and understand words, pictures and symbols that leads to overcoming tragical antinomy of "the cosmic reality" and "the apparent reality of the world". Regarding this, Bely tries to concentrate to the sound aspects of the word to discover proto-language as the unity of sound, sense and being. Thus, he attempts to enrich the words for esoteric sense and create the word-symbol ("sound-picture") that reunites the sense of picture and the sense of the sound and makes for the birth of the consciousness of the word. The final result of this creative process represents an approach to the transcendent reality. According to the anthroposophy of $\mathrm{R}$. Steiner, we reach the state of being when human body is permeated by rhythms and harmonic pulsations of "etheric body": “..мыслить - вести разговор с существом, воспоминанье о коем - понятие; в начале нам слово и мысль: но до начала еще - наша память. Мы не мыслим, мы помним; и мы называем какой-нибудь термин; за термином-мрак, пустота, - Ding an sich или res (все почтенности онтологии, о которой мы путного слова сказать не умеем). Так вспомним же? И память о памяти спит; память в нас коротка: вспомним термин; и - только... Образ мысли есть единство; преодолеть раздвоенье словесности - значит: преодолеть и трагедию мысли без слова; и вспомнить, что есть память о памяти - или сложение речи: творение нас и всего, в чем живем, потому что звук речи - есть память о памяти... Да будет же братство народов: язык языков разорвет языки; и свершится второе пришествие Слова". (Белый 1994 (2): 46, 47)

Bely's aesthetic theories have, above all, wide semantic, ethical, philosophical and spiritual context. He understands the art as the means by which our being could be transformed to the spiritual one: "Символистическое течение современности, если оно желает развития и углубления, не может остаться замкнутой школой искусства; оно должно связать себя с более общими проблемами культуры; переоценка эстетических ценностей есть лишь частный случай более общей работы - переоценка философских, этических, религиозных ценностей...” (Белый 1910: 8) [...] “...искусство - не только искусство; в искусстве скрыта непроизвольно религиозная жизнь. Последняя цель культуры - пересоздание человечества; в этой последней цели встречается культура с последними целями искусства и морали; культура превращает теоретические проблемы в проблемы практические; она заставляет рассматривать продукты человеческого прогресса как ценности; самую жизнь превращает она в материал, из которого творчество кует ценность. Такое внутреннее освещение человеческого прогресса (его переоценка), придавая ему органическую целостность, превращает самое понятие о прогрессе в понятие культуры... идеал красоты - идеал человеческого существа; и художественное творчество, расширяясь, неминуемо ведет к преображению личности; Заратустра, Будда, Христос столько же художники жизни, сколько и ее законодатели; этика у них переходит в эстетику, и обратно...” (Белый 1994: 23)

The real art represents for him "brilliant knowledge", which leads to enlarging the borders and forms of our world view and cognition. The basic aim of the symbolism is the effort 
to interconnect the aspects of timeless world of Platonic ideas with space-time aspects of our being and finally to realize it by the art pictures: "Искусство есть гениальное познание. Гениальное искусство расширяет его формы. В символизме, как методе, соединяется вечное с его пространственными и временными проявлениями, встречаемся с познанием Платоновых идей. Искусство должно выражать идеи. Всякое символистическое познание идейно". (Белый 1994: 246)

The symbolism, which is also Bely's opinion, must elucidate and understand the deepest contrasts of contemporary culture. In the context of symbolism, Bely sees the human culture as one great unity. Its separate periods with their typical symptoms thanks to this conception do not represent only "dead forms", they are rather understood as the living pictures and modes of being that give testimony of the way of human consciousness and culture towards more complex self-awareness and self-knowledge: “...в символизме есть попытка осветить глубочайшие противоречия современной культуры цветными лучами многообразных культур; мы ныне как бы переживаем все прошлое: Индия, Персия, Египет, как и Греция, как средневековье, - оживают..." (Белый 1994: 26)

The problems of sense are symptomatical for aesthetic-philosophical theories of A. Bely. Searching for the sense of particular artefacts and culture complexes, Bely considers in connection with the theory of values. Thanks to it our world view and our knowledge of the world becomes the creative power where philosophy and other science system gain symbolic sense which reflects basic values of our life. The cognitive value hidden in art leads, according to Bely, to the creation of ideas-pictures and the awareness of them represents real essence of all things, their objective reality: “...сама же теория знания в своей метафизической форме есть ликвидация твердынь чистого разума; в результате такой ликвидации мировоззрение как теория переходит в творчество”. (Белый 1994: 36)

In his book of essays "Арабески" (1911) Bely claims that the basic principle of symbolism is an effort to use the picture of reality as the means by which the inner contents of consciousness is reflected. Presented picture - symbol becomes a particular model of the world of experience of consciousness and the method of symbolization of these experiences through pictures is the real symbolism. Similarly, this problem was seen also by the next representative of Russian symbolist - Ellis: “Символ - веха переживаний, это условный знак, говорящий: Вспомни о том, что открылось тебе тогда-то, о чем грех рассуждать и смешно спорить... Иногда символ говорит: $Я$ помогу тебе вспомнить и снова пережить это. Так я смотрю на свой собственный символ - золотое руно. Это условный знак, это рука, указывающая, где вход в дом, это фонограф, кричащий: Встань и иди... но содержание этого символа дает мне мой интеллект и моральный инстинкт, который развит раньше, чем я придумал символ руна." (Лавров 1978: 140-141)

Every kind of art is, according to Bely, in its deepest essence symbolical and the pictures created by it are always the result of integration of forms, means and inner spiritual values (“соединение слов с плотью...” [Белый 1911: 397]): “В искусстве мы познаем идеи, возводя образ к символу. Символизм - это метод изображения идей в образах. Искусство не может отрешиться от символизма, который может быть то замаскирован (классическое искусство), то явен (романтизм, неоромантизм). В искусстве всегда есть нечто соединяющее. Здесь берется момент, когда раздвигаются складки мировой паутины: то, что было 
внешним, перестает им казаться. Сопоставление предметов или частей его с другим предметом возводит данный предмет в нечто третье. Это третье становится отношением, соединяющим многое в одно, то есть символом".

In the theories of young symbolists, symbol has stopped being only clear technological element of text producing and started to be universal means by which the parallel existence of picture in real and transcendent mode is now possible. In connection with that we can see in Bely's work of art creating of parallel worlds in his poems and novels.

Symbolistic art is above all presented here as the aesthetic-philosophical projection of human pilgrimage to the higher modes of being. Thus, the most of the artworks of A. Bely are filled with symbols of circle and spiral (we can also meet them in mythological texts). Here Bely uses them as the symbol of Eternal Return, cyclic regeneration, transformation (circle) and as the symbol of continuous circular move of endless line towards the spiritual centre (spiral): “... если прямая символизирует безвозвратное прохождение мимо, то круг - вечное возвращение, кольцо возврата. Обе линии связаны друг с другом эллипсисом... В спирали совмещение прямой и круга... Разлагая движение спирали высшего порядка, мы получаем движение круговое и по прямой. Но если эта прямая - спираль низшего порядка, то она, в свою очередь, разложима на прямую и круг. Продолжая так до бесконечности, мы получим графическое изображение прямой и ряд колец нанизанных друг на друга. [...] В спиральном путешествении души сквозь время замечаются периоды приближения к поверхности - периодические возвращения Вечности". (Белый 1994: 252)

Symbolism, according to Bely, represents the first attempt to find and adequately express the presence of eternal and endless element in the reality. The greatest ambition of symbolism is to realise the theurgical principle in the art: “Если в символизме мы имеем первую попытку показать во временном вечное, в теургии - начало конца символизма. Здесь уже идет речь о воплощении Вечности путем преображения воскресшей личности". (Белый 1994: 253) Symbolism carries unique cognitive value. Through the integrated and organically linked figurative cognition creating of mentally concentrated and living forms is realized. The art creation leads to the unlocking of "world logos" in the heart of human being and human culture. The realization of this symbolical unity is finally close to the message of The Book of Revelation which became very popular in the spiritual context of the literary symbolism: "Символическое единство есть единство ряда познаний в ряде творчеств; но уже при метафизическом определении этого ряда мы раскалываем единство. Все то же единство венчает лестницу творчеств, являясь нам в образе и подобии человека; вот почему лестница человеческого творчества оканчивается уподоблением человека этому единству; говоря языком религий, творчество ведет нас к богоявлению; мировой Логос принимает лик человеческий; вершина творчества указывается словами Апокалипсиса: Побеждающему дам сесть со Мной на престоле Моем, как и я победил и сел с Оти,ом на престол Его". (Белый 1994: 52)

\section{4 / THE CONSTANTS OF THE SYMBOLISM OF OTOKAR BR̆EZINA}

If we want to get more familiar with the creative world of Czech symbolist Otokar Březina, we have to carefully study his poetic essays ("Hudba pramenư", "Skryté dějiny" and other), his rich 
correspondence with his friends and famous representatives of the art of the turn of the century and, last but not least, his collections of poems. Just this way we can make a complete picture about his aesthetic-philosophical system.

\section{5 / THE SENSE OF THE ART}

According to Březina the "great mystical power" is hidden in every kind of art and its history represents the history of human soul. The art surrounds human with new mysterious world which is entered by his soul. Březina represents the sensitive literature which is filled with "inner life" and which is "renewed by the soul". The literature should express the life not only by its outer forms but mainly by the inner forms thanks to it the "mysterious heart of things", the soul of the art appears: "Nejde mi o to, abych čtenáře bavil, umění, jak dneska je cítím celou svou duší, není a nebude pro potravu davu; moderní báseň zavírá určitý komplex myšlenek, obrazů, nálady, barev, již prožije, vsaje, otiskne v sobě jen duše př́ibuzná, schopná meditace, vzletu a nadšení; každé slovo, každý obrat, každý obraz musí být studován, odhadnut, odkryt, ochutnán, vážen, pojat. Jako byl umělcem v inspiraci fixován, prohlouben, v mozaiku rytmů zasazen. [...] nám, kteří tvoříme, musí státi se umění fixní ideou, s níž leháme, spíme a vstáváme, žijeme, pohybujeme se, vnímáme; jen tak, zesíleným tímto interním životem, obráceným v jediný Kruh, rozpadne se před námi ztuhlá pečet neznámého a promluví myšlenka." (Březina 2004: 268, 272)

The ideal of a real poet is, according to Březina, hidden in the creative person who is endowed with clear and intensive vision of life, increased sensitivity, presence of spiritual vision of eternity and he also has to govern deep intuition of the aspect of nature and the power of language. Only then, the poet is able to realize creative spiritual work and to read the light signs of eternity in the reality.

The means for creating the real poetic work of art are abilities to express feelings and ideas that going through the essence of reality. Consequently, they live they own life independent of temporality and they also do not lose their "magic power" to initiate new knowledge and new aspects of comprehension: “...jen velké umění a velká láska (což je konečně totéž) dovedou sestoupiti tak hluboko $\mathrm{k}$ pravdě a $\mathrm{v}$ tazích, chvějících se ještě životem, postřehnouti záření duše, zrající pro věčnost. Nebot počínáme člověka v duchovní jeho pravdě viděti teprve tehdy, až když ho milujeme." (Březina 2004: 1132-1133)

The basic aim of new art is tightly connected with the basic sense of culture, history and evolution of ideas. The main mission of human soul is to express supernatural beauty, to contribute the creation of ideal and deep art that could discover its unknown relationships with the Cosmic being. The poet also must relate his work to music. It allows to reflect the emotional states and experiences and it is not possible to express them by the words. The poetry must believe in the transcendent meaning of life, because all the highest thoughts are close to prayers.

The art also has its psychological meaning, for it applies to the relationship of the souls that are understood as a transcendent object. Every process which takes place in our soul refers to the transformation of transcendent energies in the polyphony of the Cosmos. In every artwork the life of creator as a magical reality is hidden. It is something like "spiritual essence of the moments" when the artwork is arising: "Proto se dívá jinak na včerejšek a jinak na dnešek; v jeho duši se ustavičně jasní. Jeho včerejší pravda neubíjí pravdu dnešní, ale jeho pravda je 
prohloubená, nově osvětlená, v novém okolí a v nových vztazích pozorovaná pravda včerejší, nebot duše mistrova hoři žízní po světle. [...] Má oči skutečně plné světla. Jeho láska může se třásti větry, ale nemůže zhasnouti, poněvadž prýští z jednoho zdroje s jeho životem. A nádhernými obrysy platónské ideje prozařuje teskným vadnutím pozemských barev do jeho duše věčná pravda." (Březina 2004: 357)

\section{6 / THE SYNTHESIS}

In aesthetic-philosophical conceptions of O. Březina we can see, as much as in conceptions of Russian symbolists, immediate influence of V. S. Solovyov. As a proof we can point out a lot of references to Solovyov's philosophy in Březina's correspondence, where he often mentions the work of art of Russian philosopher (see for example his letters to E. Chalupný).

There are some Březina's thoughts that are very similar to Solovyov's ideas. The aim of human knowledge is for Březina to recognize the unity in polymorphous reality and to understand that in the depth of every individual consciousness the whole Cosmos is hidden. Every human being is therefore anchored in Absolute, draws spiritual energy from there and participates in creating its history. This individual consciousness Březina names the "consciousness of spiritual unity" and, consequently, the meaning of life and of modern civilization is the necessity of the new state of belief in "transcendent cosmic unity". Like Solovyov he sees the meaning of every art creating. The artist at moment of creation directs deeper towards the essence of the world and he realizes the spiritual unity of the Cosmos. Thus, every artist based on his unconsciousness creating recognizes inner principles of his own and establishes completely new relation with Cosmos. His senses start to feel the "world of spiritual vibrations" and his imagination gets real significance.

This way the art becomes the most powerful method of cognition that is possible to express whole polyphony of voices (the deepest tunes of death and the highest tunes of spiritual passion and beauty). This polyphony resonates in all visible things, in the history of humankind the process of the integration of our world with the highest spiritual worlds is iniciated: "Z té přičiny umění, to jest schopnost nejjemnější řečí, přistupné v tomto vtělení, čím dál více poutá člověka poznávajícího a hledajícího života. Kdo studoval dnešní okultism a zjevy vyššího psychického života, pozná brzy, že doposud na zemi dosažené vidění obou světů dálo se od géniů uměleckých, kteří byli a jsou jedinými syntetickými duchy na zemi a přetrvávají odborné učence, zakladatele věr, přesné myslitele, tvůrce systémů..." (Březina 1996: 193)

The ultimate meaning of art is to prepare the final synthesis which is understood as a connection of knowledge and dream, science and poetry and as the creation of integrated picture of cosmic being. According to Březina "hidden history" is the part of the higher system of the history that are developed in Cosmos. The rise of human soul is directly related to rise of "higher spiritual systems" to which it our world is connected. The humankind represents the unity of the past, presence and future that is connected to Cosmos. The humankind inceasingly knits to the single organism, thus we can wait for the moment when it will be harmonised by higher spiritual life: "Ale všechny reformy sociální, úsilí vizionářů a světců, šílenců a bytostí démonických, kteří dnes připravují nový svět, byly by marné, kdyby sociální vývoj nebyl provázen i čistším pohledem na život a věci, vírou ve spravedlnost světa duchovního, soucitným a laskavým vztahem po sobě toužících srdcí." (Březina 2004: 1249) 
Solovyov's Divine Humanity is understood by Březina as integrated being and every single stage of his genesis is conditional on clearer awareness of primary spiritual unity: “...obraz člověka vysvobozeného Slovem a Láskou, vždy nádherněji vztyčující se z milionů, blíží se k nám z věků. Nesčíslnými zraky pohlíží v těžký sen věcí a uvidí konečně.” (Březina 2004:525) In connection with that Březina sees the meaning of art that becomes "inner language" by which transformed human being tries to express amazement of space: "Umělec kráčí k dokonalosti svého díla dokonalostí svého života. Všechny druhy umění jsou v podstatě jedno a totéž, malba, socha, hudba, slovo osvětlují se navzájem." (Březina 2004: 526)

The highest value of art is the spiritual unity and polyphony. It is an intuition that is able to sense the connections between distant facts, to realize the rules of the genesis of Cosmos and to recognize the spiritual unity of all things of visible and invisible worlds: “...všechny formy lidského úsilí, věda, politika, hmotná práce, náboženství, veškeré dílo vášně i snu, duchovní kázně a vzdoru, dílo jasného, po ostré disociaci pojmů toužícího intelektu i podvědomých, člověkem dosud nezvládnutých sil, všechno, co vytvořilo minulost a připravuje budoucnost, souvisí vzájemně tisíci vztahy a v hloubce, kam myšlenka se blíží s chvěním, vyjadřuje jedno duchové gesto..." (Březina 2004: 804)

\section{7 / THEURGY (THE ART AND THE WORD TRANSFORMING THE WORLD)}

The art creation is seen as the belief in highest spiritual entity. According to Březina every real art creation is able to transform the life on earth, to create new relation of life and new connections between people: "Tvořícímu člověku není třeba, aby psal mnoho knih; stačí jen žíti mocně až do hlubin věčnosti a smrti vlastní svůj život, v pravý čas říci pravé slovo, a když je toho třeba, míti odvahu k mlčení." (Březina 2004: 1454)

When the world is affected by materialism and the religiosity is weakened, Březina founds that the art represents the only possible way to salvating the culture: "Umělec měl by dnes príijít jako vítězný dobyvatel, pralesy myšlenek by měly hořet v plamenech na jeho cestě a krvavé požáry házet do hlubokých polárních nocí jeho severní záře a jeho hlas měl by viřriti jako cyklon vyvracející staleté stromy a sesouvající města uprostřed orgií. A všechny tváře měl by dosinava zastrašit láskou." (Březina 2004: 361) The real poet must be creative in all levels of his existence, he not only reveals hidden beauty, but he also joins together everything around him. The main aim of the art is the nature powered by the soul that transforms everything to the concrentated forms. Everything that leads to the transformation of our relation to the material world and its perception as the unity is the spiritual effort that could be seen as the neverending fight for the beauty: "V dílech velkých milujících, jasnovidců a mistrů nabývá slovo národa magické moci: láme zakletí oddělující duchy, $v$ jednotu rozechvívá srdce zjevením krásy, v oslnění věčnosti dává viděti pozemské věci." (Březina 1996: 127)

The word, according to Březina, is able to liberate senses and thoughts, to connect souls and to transform chaos into the order and beauty and to prepare the coming of new human and new earth.

To control the word means to resurrect its creative power and to turn the art into religious act. Thus, the word becomes a means to "reach higher worlds": "Zasvěcení slova, věštecká 
zjevení hudby! [...] Zachvění štěstí, když duše dotýká se duše, nahá v extázi chóru! Hymnus věříího množství sjednoceného, valící se jako bouře, strhující všechny př̌kážky a opevnění, útokem ženoucí k valům věčného města! Polyfonie, v nichž všechny živly a bytosti nabývají hlasu a boj proti sobě pracujících vưlí smiřuje se v nebeských utišeních harmonií.” (Březina 1996: 107)

\section{8 / THE RENAISSANCE OF THE SOUL ("SELF")}

Like number of other symbolists, Březina very often thinks about the problem that famous psychologist C. G. Jung called "self", "unconscious" and "archetypes". If the art represents the symbolic bridge between visible and invisible worlds, it is, according to Březina, possible to reflect the deepest collective values, where human souls meet and where the knowledge of the secrets of the world is united. In every single human there exists timeless spiritual being, which is endowed with the inner sight of invisible that lights past, presence and future and unites all of them to "brotherhood of seers and sacred": "Př́šerně slavné zkušenosti tohoto zraku neuvědomují se v duši po čas života na zemi v celé smrtelné nádheře svého bohatství.” (Březina 1996: 8) [...] "Zastaven v rozpětí vnějším vstupuje člověk do hlubin a nalézá v duchovní sféře nových sil, aby mohl konati tu část věčného díla, která mu byla uložena..." (Březina 1996: 1214)

Thus, in the real personality the unity of the visible and invisible cosmos is reflected and any spiritual needs and values of human culture are formed in harmony with that. Consequently, Březina sees the art creation as the motion of the soul from depths of unconscious, where the profane dimension of human existence is connected to the higher cosmic life. Every work of art is understood as the work created by "million brothers" and as the "incarnation of gigantic dream which develops for ages": "Jen v zasažení proudu, který rozžehuje všechna slunce a rozvíjí země, který tvoří dějiny, zdvihá a vede davy, buduje a třiští říše, s oslňující nádherou pracuje v neviditelném a který $v$ jediné bytosti dává procitnouti celému rodu, rozsvěcují se tvưrčí zraky a rozvazuje jazyk.” (Březina 1996: 63) [...] “Celkové vědomí lidstva jest síla, které žádný génius však nedosáhl; je nepopiratelné, že tato síla vzrůstá a že jednou bude silnější nežli síla větrů, moří, proudů elektrických, probíhajících zemí...” (Březina 1996:189)

In his essay called "Zrcadlení v hloubce" Březina talks about "springs of knowledge", which we need to go down to, about hidden affinity of all art works given by the existence of inner space of "only spirit". The traces of this "only spirit" are visible in every kind of art form from the prehistorical to the contemporary periods of human culture. On the basis of these traces, we can finally recognize the "liberating dogmas of beauty" and the art creating becomes the analogy to dreaming, when the artistic relevation into "inner sight of humankind" is projected: “To jsou teprve okamžiky hodné početí krásy, chvíle, kdy tvůrčí duch smiřuje a tiší zmatená vření všech srdcí, dýchá všemi rty, jako v půdu seje do plamenů, určuje dílo pro tisíce rukou a za nesčíslné zraky do budoucnosti vidí. Dokud umělec nedošel na místa, odkud všechny cesty kromě jeho vlastní jsou mu neviditelné, daleko má ještě k své svobodě.” (Březina 1996: 74-75)

The intuitive lighting of the hidden spiritual processes and going down to them is the necessary condition of art creation, because the biggest dramas according to Březina take place at the bottom of the human soul. Thus, the art and, above all, the lyric poetry is the most suitable form for unlocking of semi-conscious depths "lighted by secret rays of Unknown". 


\section{9 / THE SYMBOL AND THE SYMBOLISM}

Březina's concept of the symbol and the symbolism as the basic principle of contemporary art is connected with the view of the structure of human personality. According to him the language still reflects minimal fraction of the deepest contents that explains the meaning of the existence of the world and humankind. The most serious of them are hidden in the symbols of pain and the anticipation of the "light flood", in the symbols of the power and the lightness and in the symbols of "secret rest of things" metamorphosis of which correspond to the evolution of our inner truth. Every art is conditioned on the "experience of inner sight" and the music is the only art form which is able to seek the language filled with symbols. In his essay "Krása světa", may be, sounds precise definition of symbolistic art: "Krása světa je skrytá. Tisíce pohledů ztrácíme marně, poněvadž nedovedly uviděti svět v okresích jejího proměňujícího a očištujícího záření. Neznáme celého bohatství vlastních svých krajin. Sotvaže v slunci svého poledne dovedeme se orientovati podle svého stínu o tajemných světových stranách." (Březina 1996:31)

The main mission of contemporary artist is to realize some hidden processes in the art and to be focused on the fact that in every artwork the meaning, sound, accent, and mood of each word and the presence of conscious and unconscious association are very important. The real artist also has to extend the rage of human perception, to cultivate and to free the "rays going through the invisible" that help to uncover the new pictures in our reflection of the world and to mediate the knowledge of the coherence between the profane and the sacral, the material and the spiritual and the real and the transcendent: "Každá myšlenka, i ta nejchudší a nejvšednější je schopna rozpáliti se v oslňujícím lesku zavedením vnitřních proudů. Každá je schopna projíti všemi uměními, ze staletí do staletí, vládnouti mramorem a oběma světly, v celé základní síle položena hudbou. Každé umění je halucinací z opojení nejsubtilnějších rytmů éteru a krve. Symbolické stíny, za jitra ukazující k západu a příštímu svítání večer, pohybují se v každém daném okamžiku u všech umění v jediném směru, dle stoupání mystického dne a dlouhého slunečního roku staletí a duší. Bolest všech uměleckých snění je vzpomínkou na hlubiny, do nichž se duše odvážila až př́liš daleko." (Březina 1996: 10)

According to Březina the values of the art come from the only spiritual source and the main aim of the symbolism is to approach the beauty of art to this inner source. This way the artist is able to feel the magic lighting shining from common depths and to transform it into the art pictures filled with deep sense of eternity: "Jen $v$ těchto chvílích nalézaly ruce malír̆u nejvýmluvnější linie plné tajemství, a barvy třené v neviditelné vláze druhého světla nabývaly svítivosti nemocné extází, jež vlévá do duší nepokoj krásy, této žízně po neznámém a jedné z nejjemnějších a nejsilnějších bolestí země. $V$ nich zvonily do tvưrčího ticha halucinace nikdy na zemi neslyšených symfonií, jež zachyceny mdle pozemskými tóny kř́sí nostalgie po čistším životě, nežli je život našich dní, a dávají pochopiti duším, že jejich dějiny nepočínají narozením ani že nekončí smrtí." (Březina 1996:21)

Due to symbols our senses by which we reflect the reality are transformed into the higher one which allows artist to perceive the cosmos as the whole. Thus, the visible world is penetrated by the invisible one. The symbol is able to visualize this invisible world and to discover the spiritual essence of the seen object. All the art forms have symbolistic nature, the signs of transcendent reality are hidden in them. The speech of symbols represents the speech of the higher 
metalanguage order, so that the symbol can't be interpreted in a single way that could eliminate the next interpretation. The symbol in that case convey the web, the system or the field of force of spiritual relations.

The energy of "invisible world" is transposed into the art work: "Ale při tom všem, třeba věky a dálky ležely mezi jednotlivými výtvory uměleckými, je to v závratných rozlohách vnitřního vesmíru přece jen jediná zem, která svými symboly v umění se zrcadlí, a jediný duch v ní trpí a na svém osvobození pracuje." (Březina 1996: 73) [...] "Co je viditelno tvůrčímu duchu, je viditelno jen ve světle, jež se řine $\mathrm{z}$ vyššího života $\mathrm{v}$ kosmu. $\mathrm{V}$ pohádkách pravěku, $\mathrm{v}$ mýtech, $v$ tajné vědě i ve snech tak jemných a neuvěřitelných, že bylo třeba utvořiti zvláštní jazyk symbolů, hudby a tvarů, aby mohly býti zdaleka naznačeny, udržovalo po tisíciletí naději na ovládnutí živlů laskavou mocí ducha." (Březina 1996: 79) Symbolistic art makes it possible to establish new relations with the Cosmos. Thanks to that, human senses are able to perceive "another world of spiritual vibrations" and the artistic imagery becomes the mightiest method of knowledge. The world-symbol has its magical power which gives us the opportunity to divine the hidden forces of the Cosmos, to recognize the feeling of immensity and the richness of the world when the slightest event appears as a gesture of eternity and initiation into secrets of the Great Unity.

\section{0 / CONCLUSION}

Based on the researched issues, it can be undoubtedly stated that there are visible similarities between aesthetic-philosophicals conceptions of A. Bely and O. Březina. In our view there is a certain hidden bond between the two representatives of the wider and deeper understanding the literary symbolism who had never met each other. Both authors refuse to understand the symbolism as the specific art movement and exactly defined literary school. They see it, above all, as the way of thinking and understanding the world (modus cogitani) and the being in it (modus vivendi). Bely and Březina as the poets and thinkers without doubt overcome aesthetic context of the modern literature of the $19^{\text {th }}$ century influenced by philosophical systems of Schopenhauer and Nietzsche and by the aesthetics of poètes maudits. They create an integrated complex of the philosophical and the aesthetic approaches that moves it towards understanding of art creation as the means of the cognition and the creating of the real world called the theurgy by V. S. Solovyov. This way they make the conception of the art creation that turns to sophisticated aesthetic-philosophical system that allows holistic knowledge of the reality and up to now unknown connections between human being and the being of the Cosmos.

\section{HIDDEN AFFINITIES OF ANDREY BELY AND OTOKAR BŘEZINA}

SUMMARY In the article we aim to find out a hidden bond between aesthetical worlds of Russian and Czech symbolists A. Bely and O. Březina. They both do not see symbolism as a connected complex understanding of development of art as specific branch of art or exactly formed literary school. They see it, first of all, as the way of thinking and understanding the world (modus cogitandi) and the way of existence inside that (modus vivendi). In our opinion, in their work of art both the poets and thinkers overcome ideological and aesthetical context of the 
Modernism, having been born in 90's and influenced by thinking of Shopenhauer, Nietzsche and aesthetical crede of poètes maudits. They form a complex of aesthetical and philosophical approaches that move symbolism towards understanding art creation as the means of learning, and forming real world, in other words art work being understood as theurgy. This way they form a concept of art creation that overgrows into detailed aesthetic-philosophical system that makes possible to recognize reality in its complex and to recognize connections between human and Cosmos that had not been seen before.

\section{REFERENCES}

I Белый А., 1995, Основы моего мировоззрения. Литературное обозрение, № 4/5, Москва, c. $13-21$.

I Белый А.,1994, Символизм как миропонимание, Москва.

I Белый А., 1910, Луг зеленый: Книга статей, Москва.

I Белый А., 1911, Арабеск, Москва.

I Белый А., 2005, О теургии. Новый nуmь, № 9.

I 1922, Памяти Александра Блока, Санкт-Петербург.

I Белый А., 1910, Символизм: Книга статей, Москва.

I Белый А., Глоссолалия - поэма о звуке, www.rvb.ru/belyi [cit.: 30. 5. 2006] (по изд. Белый А., 1994, Глоссолалия-поэма о звуке, Томск) (2).

I Лавров А. В., 1978, Мифотворчество аргонавтов. Миф-фбольклор-литература, Ленинград, с. 137-170.

I Březina O., 2004, Korespondence I., Brno.

I Březina O., 2004, Korespondence II., Brno.

I Březina O., 1996, Eseje, Olomouc.

I Elsworth J. D., 1983, Andrey Bely: a critical study of the novels, Cambridge.

I Christa B., 1977, The Poetic World of Andrey Bely, Amsterdam.

I Papoušek V. a kol., 2010, Dějiny nové moderny: česká literatura v letech 1905-1923, Praha.

I Спивак М., 2006, Андрей Белый. Мистик и советский писатель, Москва.

I Vojtěch D., 2008, Vášeň a ideál. Na křižovatkách moderny, Praha.

I Vojvodík J., 2004, Od estetismu k eschatonu: modely světa a existence v lyrickém díle Otokara Březiny: rekonstrukce symbolických paradigmat, Praha.

I Wiendl J., 2007, Vizionáři a vyznavači. Kotázce sepětí řádu umění a života v české poezii první poloviny 20. století, Praha. 